\title{
ANALISIS KONSTRAIN DAN SUSTAINABILITAS PENGEMBANGAN PERTANIAN DATARAN TINGGI PEGUNUNGAN ARFAK DI PAPUA BARAT
}

\author{
Meky Sagrim ${ }^{1,2}$, Agus I. Sumule ${ }^{1,2}$, Deny A. Iyai ${ }^{2,3}$, Michael Baransano ${ }^{1,4}$ \\ ${ }^{1)}$ Jurusan Sosial Ekonomi Pertanian. Fakultas Pertanian. Universitas Papua. \\ Jl. Gunung Salju, Amban. Manokwari-Papua Barat. \\ email: meckysagrim@yahoo.com \\ ${ }^{2)}$ Pusat Penelitian Kependudukan dan Sumberdaya Manusia (P2KSDM). Universitas Papua. \\ Jl. Gunung Salju, Manokwari \\ ${ }^{3)}$ Jurusan Peternakan. Fakultas Peternakan. Universitas Papua. Jl. Gunung Salju, Amban. \\ Manokwari-Papua Barat. Kode Pos 98314. \\ ${ }^{4)}$ Mahasiswa Program Pascasarjana (S3) Institut Pertanian Bogor (IPB)- \\ Bogor. Jl. Darmaga. Bogor, Jawa Barat.
}

\begin{abstract}
The variability and complexities of limiting factors in development have been exist in community. Works in agriculture sector need lot of attention in development plan. Therefore, it needs a concise study of constraints and future agriculture development. A descriptive study and FGD technique and snowball sampling method were used to approach local community in gaining related information. The findings reported that the primary constraints hampered local communities were farmers' motivation, state officers' performances, and capital investment performances. The available quality seeds and breeds will have strategic position in planned agriculture development.
\end{abstract}

Keywords: constraints, Pegunungan Arfak, problem tree, sustainability, SWOT

\section{PENDAHULUAN}

Sebanyak 7.326 KK dilaporkan sebagai kepala keluarga di Kabupaten Pegunungan Arfak (BPS Pegaf, 2015). Dengan jumlah penduduk adalah 26.729 jiwa, Kabupaten Pegunungan Arfak (Pegaf) adalah kabupaten yang relative baru atau daerah otonomi baru (DOB) yang ada di provinsi Papua Barat yang dibentuk dengan UU No. 24 Tahun 2012. Karena DOB maka sistim matapencahariannya sebagian besar (>90\%) bersumber pada pertanian. Hal ini menjadi ciri kebanyakan penduduk Indonesia yang bermukim pada daerah-daerah pedalaman atau pelosok kampung (Sutrisno, 1999). Kabupaten Pegaf adalah hasil pemekaran dari kabupaten induk, Manokwari. Tentunya sebagai DOB, potensi sumberdaya alamnya perlu dikembangkan sebagai modal utama roda penggerak ekonomi masyarakat Pegaf. Hal ini mengingat, kontribusi sektor pertanian baru mencapai $74.6 \%$ terhadap PDRB. Oleh sebab itu, untuk meningkatkan nilai kontribusi sektor, maka perlu diketahui batasan-batasan yang menghambat atau menjadi konstrain percepatan pembangunan pertanian. Luas lahan yang ada di Pegaf adalah $\pm 2.773,74 \mathrm{~km}^{2}$ dan jumlah penduduk \pm 25.859 jiwa yang tersebar di 166 kampung meruapakan asset penting sebagai penggerak pembangunan. Beberapa studi melaporkan bahwa komoditi pertanian termasuk peternakan (Tim Unipa, 2015; Yantewo, 2015 dan Meidodga, 2015) dan antropologi (Deda et al. 2009). Hasil kajian Tim Unipa (2015) menyebutkan bahwa terdapat tanaman sayuran dataran tinggi, buahan-ubi-ubian dan tanaman jangka panjang. Hal yang sama juga dituliskan oleh Mulyadi (2012) serta Sagrim et al. (2015). Hal ini berarti bahwa sektor pertanian dapat menjadi sektor unggulan di Kabupaten Pegaf, walaupun produksi potensialnya masih harus dinaikkan. Upaya ini sejalan dengan visi dan misi pemerintahan definitif Saroy dan Mandacan periode 2016-2021 (Naskah visi dan misi Bupati dan Wakil Bupati Pegaf, 2015). Namun sejauh ini belum diketahui konstrain yang membatasi produksi dan kinerja sektor pertanian dataran tinggi Pegaf. Tujuan penelitian ini adalah untuk mengetahui faktor-faktor pembatas (konstrain) pembangunan pertanian dataran tinggi di Kabupaten Pegaf.

\section{METODE PENELITIAN}

Penelitian ini dilaksanakan pada bulan November-Desember Tahun 2015. Lokasi sampel adalah pada 7 distrik dari 10 distik yang ada di Kabupaten Pegunungan Arfak, 
yaitu Sururey, Anggi, Taiga, Minyambouw, Didohu, Anggi Gida, Hingk. Penentuan lokasi sampel didasarkan pada tingkat aksesibilitas yang dapat dijangkau serta karakteristik penduduk yang homogen baik dari segi sebaran kelompok suku yang mendiami wilayah tersebut maupun mata pencahariannya. Letak Geografis Kabupaten Pegunungan Arfak adalah pada bagian Utara $0^{\circ} 55^{\prime}$ Lintang Selatan, pada bagian Selatan $1^{\circ} 40^{\prime}$ Lintang Selatan, pada Bagian Barat $133^{\circ} 10^{\prime}$ Bujur Timur, dan Bagian Timur $134^{\circ} 05^{\prime}$ Bujur Timur. Letak lintang dan ketinggian lokasi penelitian berada pada $>2000$ mdpl. Rata-rata curah hujan tahunan adalah $260,82 \mathrm{~mm}$, rata-rata hari hujan per bulan adalah 20,92 hari. Suhu udara minimum $27,08^{\circ} \mathrm{C}$, sedangkan suhu maksimum $27,80^{\circ} \mathrm{C}$ dengan rata-rata suhu udara adalah $27.49^{\circ} \mathrm{C}$, rata-rata kelembaban udara adalah $84,07 \%$. Jumlah kampung yang dijadikan sampel adalah sebanyak 14 kampung, dengan jumlah responden sebanyak 60 . Penentuan responden didasarkan atas sebaran kelompok sub suku Hatam sebanyak 30 responden di sebelah utara meliputi wilayah distrik Minyambouw, Hingk, Anggi dan Taige serta 30 responden lainnya di sebelah selatan yang merupakan wilayah sebaran kelompok sub suku Sough meliputi wilayah distrik Didohu, Sururey dan Anggi Gida. Penentuan responden di masing-masing wilayah dilakukan dengan teknik snowball dan wawancara mengacu pada 19 butir pertanyaan terbuka (opened question) di bidang pertanian dalam arti luas yang meliputi tanaman pangan, peternakan, perikanan dan kehutanan. Waktu yang dialokasikan untuk melakukan wawancara adalah sebanyak 30-45 menit. Data permasalahan pembangunan pertanian di Pegaf yang diperoleh melalui wawancara selanjutnya dianalisis menggunakan metodeanalisis pohon masalah dan analisis SWOT yang diuraikan secara deskriptif dan disajikan dalam bentuk gambar, grafik dan tabel dengan bantuan Citra Lansat, MS Visio dan MS Excel. Analisis dilanjutkan dengan mengkaji faktor internal dan eksternal menggunakan Tabel Internal Factor Analysis Summary dan External Factor Analysis
Summary untuk menentukan faktor-faktor yang menjadi strength dan weakness maupun opportunity dan threat, selanjutnya memberikan bobot pada masing-masing faktor dari skala 0,0 (tidak penting) sampai dengan 1,0 (sangat penting) dimana total nilai bobot adalah 1,00. Pemberian rating (pemeringkatan faktor SWOT) berdasarkan skala Likert yaitu skala 1-2-3-4, Sangat Kecil-Sedang-BesarSangat Besar (Rangkuti, 2009; Faisal, 2008).

\section{HASIL DAN PEMBAHASAN}

\section{Analisis konstraint}

Kebutuhan penyelesaian permasalahan pertanian berdasarkan identifikasi masalah pada Gambar 1, dilakukan sesuai hasil depthinterview dengan stakeholder di Kabupaten Pegaf, maka pembangunan pertanian dilakukan melalui pendampingan teknis budidaya pertanian terutama menyangkut tindak-tindak agronomis, pembentukan lembaga tataniaga yang berfungsi menyalurkan produk-produk pertanian milik warga; penyediaan angkutan khusus untuk melayani mobilisasi produk-produk pertanian ke pasar, penyediaan ruang informasi hargaharga produk pertanian yang berlaku di pasar, pemberian bantuan peralatan bercocok tanam dan pelatihan dan pendampingan penggunaan peralatan bercocok tanam. Hal yang sama direkomendasikan oleh Sudiyono (2004), Soekartawi et al. (1986), dan Soekartawi (2010).

Untuk pengembangan komponen sub sektor komoditas pertanian terdapat sejumlah faktor pembatas (limiting factors). Untuk itu dilakukan tahapan identifikasi permasalahan pertanian (agricultural constraints) di Kabupaten PEGAF dimulai dengan menggunakan analisis pohon permasalahan (problem tree analyses). Masalah umum yang terjadi adalah performans/kinerja pembangunan pertanian rendah. Hal ini disebabkan oleh tiga (3) hal yaitu rendahnya motivasi bertani, pelayanan instansi teknis yang rendah dan tataniaga pertanian yang belum maksimal. 


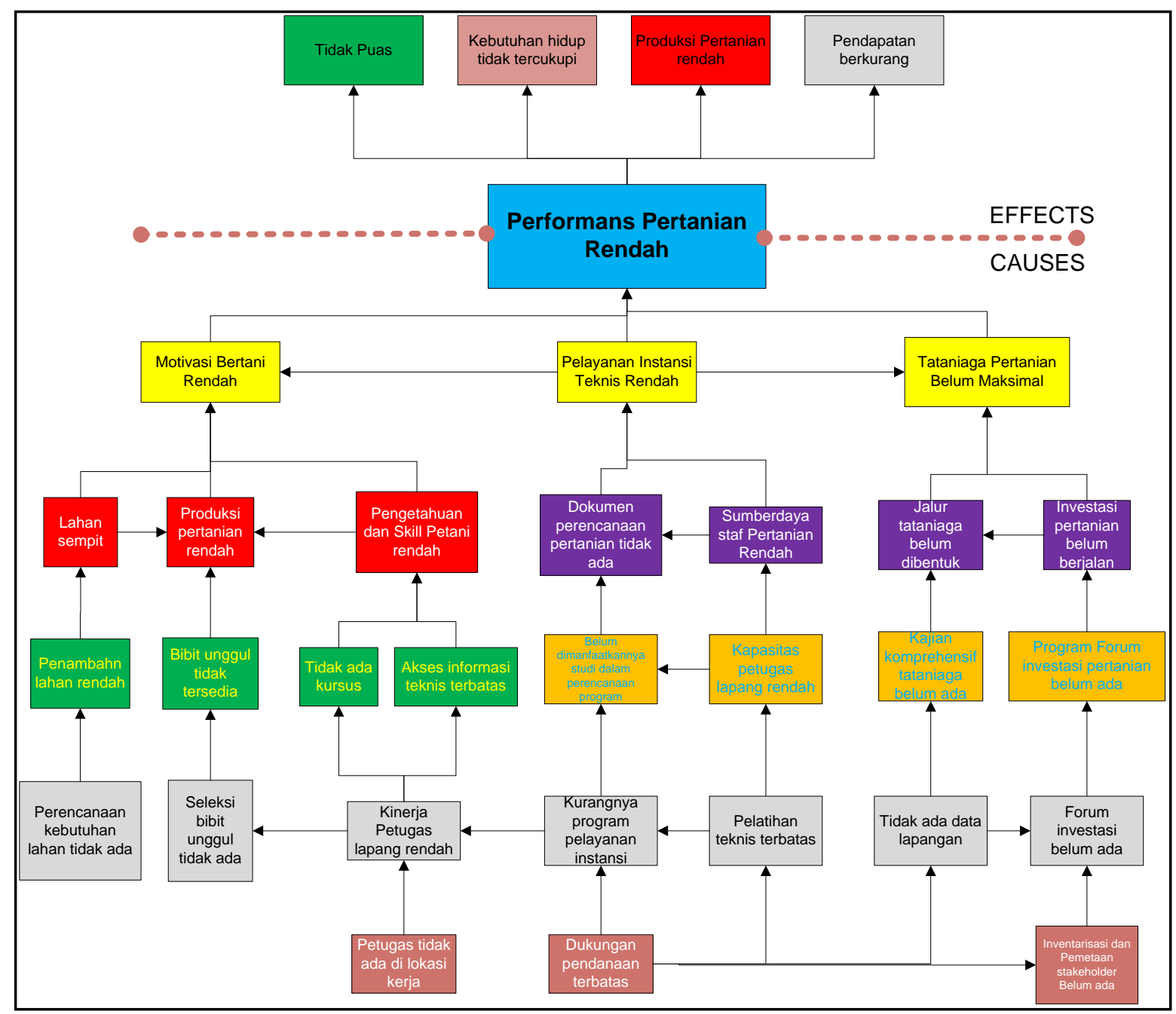

Gambar 1. Analisis pohon masalah bidang pertanian di Pegaf.

1. Motivasi bertani rendah. Motivasi rendah disebabkan oleh pengetahuan dan skills petani yang masih rendah. Hal ini berkaitan dengan latar belakang pengetahuan, keterampilan dan pengalaman usaha (Rahardi dan Hartono, 2006). Dengan skill dan pengetahuan yang rendah ini maka, produksi pertanian menjadi rendah pula. Selain itu, produksi pertanian yang rendah ini dipengaruhi dengan lahan yang diolah relatif sempit. Biasanya luas lahan $<0,5 \mathrm{ha} / \mathrm{KK}$. Lahan yang sempit ini disebabkan juga antara lain karena perencanaan kebutuhan lahan tidak ada. Disinyalir juga bahwa produksi pertanian yang rendah disebabkan oleh ketidaktersedianya bibit (bibit unggul) di Pegaf. Mengapa tidak tersedia, hal ini disebabkan juga oleh kinerja petugas lapang yang rendah dalam memberikan arahan/penyuluhan dalam upaya penyediaan bibit skala rumah tangga.
Rendahnya kinerja petugas/aparat teknis Pemda disebabkan karena ketidakhadiran mereka dalam melaksanakan tupoksi di Pegaf.

2. Pelayanan instansi teknis rendah. Disebabkan oleh sumberdaya staf pertanian yang rendah dan ketersediaan dokumen perencanaan pertanain. Ketersediaan dokumen yang rendah ini dipengaruhi oleh belum dimanfaatkannya kajian sebagai database dalam perencanaan pembangunan pertanian (Soekartawi, 1986). Belum dimanfaatkannya kajian lapangan sebagai database karena relatif kurang dilakukannya kajian/studi database. Hal ini menjadi penting dalam upaya penyediaan database bagi diselenggarakannya program pembangunan di Pegaf.

3. Tataniaga pertanian belum maksimal. Dalam perencanaan tataniaga pertanian 
ada dua hal yang penting yaitu kajian komprehensif tataniaga dan forum investasi pertanian. Belum tersedianya data lapang kinerja pertanian menyebabkan lambatnya kinerja investasi modal di Pegaf. Peran modal dalam pembangunan pertanian ditekankan oleh Dwiyatmo (2006) dan Suratiyah (2008) serta Soekartawi (2010). Hal ini juga berimplikasi pada terbentukanya forum/kelompok investasi sumberdaya alam di Pegaf.

\section{Peluang dan Tantangan Pembangunan Pertanian Berkelanjutan}

Selanjutnya penetapan strategi yang sesuai melalui analisis SWOT (Salusu, 2003) untuk menyelesaikan permasalahan pembangunan yang meliputi kesejahteraan dan pemerataan ekonomi dalam pembangunan pertanian Pegaf, disajikan pada tabel 1.

Tabel 1. Analisis SWOT pembangunan pertanian Kabupaten Pegunungan Arfak (Pegaf).

\begin{tabular}{|c|c|c|c|c|}
\hline \multicolumn{3}{|r|}{$\pi$ Th } & Opportunity (O) & Threat (T) \\
\hline \multicolumn{2}{|c|}{ Internal } & & $\begin{array}{l}\text { - Permintaan produk } \\
\text { pertanian meningkat }\end{array}$ & $\begin{array}{l}\text { - Introduksi tanaman dan ternak } \\
\text { dari luar } \\
\text { - Persaingan dengan produk luar } \\
\text { di pasar }\end{array}$ \\
\hline 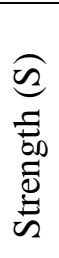 & \multicolumn{2}{|c|}{$\begin{array}{l}\text { - Tersedia lahan } \\
\text { pertanian } \\
\text { - } \begin{array}{l}\text { Komoditi unggulan di } \\
\text { tiap distrik }\end{array}\end{array}$} & $\begin{array}{l}\text { Strategi }(\mathrm{S}-\mathrm{O}) \\
\text { Intensifikasi dan } \\
\text { ekstensifikasi produk- } \\
\text { produk pertanian }\end{array}$ & $\begin{array}{l}\text { Strategi (S-T) } \\
\text { Meningkatkan dan } \\
\text { mempertahankan kualitas serta } \\
\text { kuantitas produk unggulan daerah }\end{array}$ \\
\hline 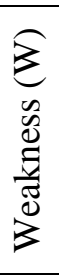 & \multicolumn{2}{|c|}{$\begin{array}{l}\text { - Belum ada } \\
\text { penyuluhan dan } \\
\text { pendampingan teknis } \\
\text { budidaya dari instansi } \\
\text { terkait }\end{array}$} & $\begin{array}{l}\text { Strategi (W-O) } \\
\text { Memanfaatkan kemampuan } \\
\text { budidaya secara tradisional } \\
\text { guna memenuhi permintaan } \\
\text { konsumsi }\end{array}$ & $\begin{array}{l}\text { Strategi }(\mathrm{W}-\mathrm{T}) \\
\text { Mengusahakan tanaman dan ternak } \\
\text { introduksi yang memiliki nilai } \\
\text { ekonomis, disesuaikan dengan } \\
\text { kearifan lokal yang ada }\end{array}$ \\
\hline
\end{tabular}

Sumber : Hasil analisis, 2015.

Berdasarkan tabel analisis SWOT di atas, dapat dikatakan bahwa faktor kekuatan dan kesempatan (S-O) memberikan kemungkinan akan dilakukannya intensifikasi dan ekstensifikasi produk-produk pertanian. Kekuatan dan ancaman (S-T) yang cukup penting lainnya adalah peningkatan dan pertahanan kualitas serta kuantitas produk unggulan daerah. Kelemahan dan kesempatan (W-O) yang dimiliki dalam rangka pembangunan pertanian di Pegaf adalah memanfaatan kemampuan budidaya secara tradisional guna memenuhi permintaan konsumsi. Hal yang menjadi kelemahan sekaligus bisa menjadi ancaman (W-T) adalah bagaimana pengusahaan tanaman dan ternak introduksi yang memiliki nilai ekonomis dan disesuaikan dengan kearifan lokal budidaya pertanian dan peternakan di Pegaf. Hasil analisis SWOT dapat dijelaskan bahwa faktor modal (Suratiyah, 2008) akan memperkuat pembangunan pertanian di Pegaf dalam ketersediaan lahan pertanian dan komoditi unggulan di setiap distrik. Komoditi unggulan pertanian adalah seperti tanaman pangan, hortikultura dan perkebunan. Selain itu, disediakannya mini ranch bagi program pembangunan peternakan. Empang dan kolam ikan menjadi modal tidak bergerak dan bergerak dalam pembangunan pertanian. Hasil analisis IFAS dan EFAS dapat dilihat pada tabel 2 dan tabel 3. 
Tabel 2. Matriks IFAS (Internal Factor Analysis Summary)

\begin{tabular}{lccc}
\hline Faktor Internal & Bobot & Rating & Skor \\
\hline $\begin{array}{l}\text { Strenght }=(\mathrm{S}) \\
\text { - Tersedia lahan pertanian } \\
\text { - Komoditi unggulan di tiap } \\
\text { distrik }\end{array}$ & 0,4 & 4 & 1,6 \\
\hline Sub Total & 0,4 & 4 & 1,6 \\
\hline $\begin{array}{l}\text { Weakness = (W) } \\
\text { Belum ada penyuluhan dan } \\
\text { pendampingan teknis budidaya } \\
\text { dari instansi terkait }\end{array}$ & 0,8 & 3 & 3,2 \\
\hline Sub Total & 0,2 & & 0,6 \\
\hline Total & 0,2 & & 0,6 \\
\hline
\end{tabular}

Sumber : Hasil analisis, 2015.

Tabel 3. Matriks EFAS (External Factor Analysis Summary)

\begin{tabular}{lccc}
\hline Faktor External & Bobot & Rating & Skor \\
\hline $\begin{array}{l}\text { Opportunity }=(\mathrm{O}) \\
\text { - Permintaan produk pertanian } \\
\text { meningkat }\end{array}$ & 0,3 & 3 & 0,9 \\
\hline Sub Total & 0,3 & & 0,9 \\
\hline $\begin{array}{l}\text { Threat }(\mathrm{T}) \\
\text { - Introduksi tanaman dari luar } \\
\text { Persaingan dengan produk luar } \\
\quad \text { di pasar }\end{array}$ & 0,4 & 2 & 0,8 \\
\hline Sub Total & 0,3 & 2 & 0,6 \\
\hline Total & 0,7 & & 1,4 \\
\hline
\end{tabular}

Sumber : Hasil analisis, 2015.

Berdasarkan tabel 4 dapat dijelaskan bahwa kekuatan/Strength (S) yang terdiri dari tersedianya lahan pertanain dan ketersediaan komoditi unggulan pada setiap distrik, dapat menjadi modal dalam meningkatkan roda aktifitas pertanian di wilayah kampung. Hasil kajian Sagrim et al (2015) menunjukkan bahwa lahan pertanian yang tersedia dengan status flat (kemiringan $<2 \%$ ) dan very gentle (bergelombang dengan kemiringan 2-8\%) adalah pada distrik Anggi dan Testega dengan persentase $17,61 \%$ dan $8,91 \%$ (total lahan tersedia adalah 26,52\%). Komoditi tanaman pangan yang memiliki keunggulan dengan nilai LQ>1 (Sagrim et al. 2015) adalah didominansi oleh palawija dan merata pada semua distik kecuali Membey dan Menyambouw. Sementara pada tanaman hortikultura dengan nilai $\mathrm{LQ}<1$ hanya ada pada distrik Membey, Minyambouw, Catubouw, Testega dan Hingk. Pada tanaman perkebunan hanya pisang yang memiliki nilai LQ> 1 adalah di Catubouw, Anggi Gida, dan Hingk. Sedangkan Jeruk dengan nilai LQ>1 hanya di Menyambouw, sama halnya dengan tanaman mangga yang nilai LQ>1 pada distrik Minyambouw dan Hingk.

Tabel 4. Rangking alternatif strategi bidang pertanian.

\begin{tabular}{clcc}
\hline No & \multicolumn{1}{c}{ Unsur SWOT } & Total Skor & Rangking \\
\hline 1 & Strategi (S - O) & 4,1 & 2 \\
2 & Strategi (S - T) & 4,6 & 1 \\
3 & Strategi (W - O) & 1,5 & 4 \\
4 & Strategi (W - T) & 2,0 & 3 \\
\hline
\end{tabular}

Sumber : Hasil analisis, 2015.

Berdasarkan pertimbangan analisis SWOT serta analisis IFAS dan EFAS di atas dan juga rangking alternatif strategi maka alternatif strategi pembangunanpertanian diarahkan sebagai berikut: Strategi I (S-T) yakni meningkatkan dan mempertahankan 
kualitas serta kuantitas produk unggulan daerah. Hal yang sama juga dilaporkan di Kendal oleh Purwanti dan Atmani (2008). Strategi II (S-O) dengan melakukan intensifikasi dan ekstensifikasi produk-produk pertanian secara umum. Hal yang sama disampaikan oleh Purwanti dan Atmani (2008) di Kendal. Strategi III (W-T) yakni dengan mengusahakan tanaman dan ternak introduksi yang memiliki nilai ekonomis, disesuaikan dengan kearifan lokal yang ada serta Strategi IV (W-O) dilakukan dengan memanfaatkan kemampuan budidaya secara tradisional guna memenuhi permintaan konsumsi.

\section{KESIMPULAN}

Konstrain yang dihadapi oleh petani dan pembangunan pertanian di Pegaf adalah motivasi bertani, kinerja aparatur pemerintahan dan modal/investasi. Faktor ketersediaan lahan dan ketersediaan komoditas unggulan daerah menjadi penting untuk ditingkatkan. Kelemahan seperti penyuluh dan pendamping (SDM) perlu diupayakan ketersediaan dan kinerjanya. Ketersediaan bibit bagi masyarakat diperlukan untuk meningkatkan produktifitas petani dan peternak.

\section{UCAPAN TERMAKASIH}

Penelitian ini berlangsung atas dukungan pendanaan dari kantor BAPPEDA Kabupaten Pegunungan Arfak, Papua Barat. Ucapan terimakasih disampaikan kepada Bupati Kabupaten Pegunungan Arfak, Kepala BAPPEDA Tahun 2015 dan masyarakat petani dan peternak di Kabupaten Pegaf.

\section{DAFTAR PUSTAKA}

Dwiyatmo, K. 2006. Kiat Menjadi Petani Sukses. Penerbit Citra Aji Parama.

Faisal, S. 2008. Format-Format Penelitian Sosial. Pt. Rajagrafindo Persada. Jakarta.

Hendarto, R.M. 2000. Analisis potensi daerah dalam pembangunan ekonomi. Makalah Diklat. Fakultas Ekonomi. Universitas Diponegoro, Semarang. Jawa Tengah.

Hendayana, 2003. Aplikasi metode Lq dalam penentuan komoditas unggulan nasional. Informatika Pertanian. Vol. 12.

Meidodga, P. 2015. Sistim pemeliharaan ternak sapi (Bos sondaicus) di Dataran
Tinggi Distrik Minyambouw Kabupaten Pegunungan Arfak. Skripsi. Universitas Papua. Tidak Diterbitkan.

Mohammad, S. 2008.Matriks dan Scenario dalam Strategi. Upp Stim Ykpn. Yogyakarta.

Mulyadi, 2012. Budaya Pertanian Papua; Perubahan Sosial dan Strategi Pemberdayaan Masyarakat Arfak. Penerbit Karta Media. Yogyakarta.

OTK Kabupaten Pegaf, 2013. Perda Kepala Daerah Pegunungan Arfak No. 01 Tahun 2013 Tentang pembentukan organiasi dan tata kerja perangkat daerah Kab. Pegaf.

Prasetyo, M.E., B.M. Setiawan, Setiyawan. 2006. Analisis faktor-faktor yang mempengaruhi pengembangan peternakan di Jawa Tengah. Journal Of Animal Agriculture Socio-Economic. Vol. 1.(1). 2006.

Purwanti, E.Y. Dan H.D. Atmani, 2008. Analisis sektor dan produk unggulan kabupaten tegal. media ekonomi dan manajemen. Vol. 18. No. 2. Media Informasi dan Manajemen.

Rahardi, F. Dan R. Hartono. 2006. Agribisnis Peternakan. Edisi Revisi. Seri Agribisnis. Agribisnis Peternakan. Penebar Swadaya.

Rangkuti, F. 2009. Analisis Swot Teknik Membedah Kasus Bisnis. Edisi Keenam Belas, Pt. Gramedia Pustaka Utama, Jakarta.

Sagrim, M., O. Kambuaya, M. Baransano, M. Bajari, I.L.S. Sinon, Krisnawati, D.A. Iyai, R. Husein. 2015. studi identifikasi dan inventarisasi permasalahan dan kebutuhan pembangunan daerah Kabupaten Pegunungan Arfak. Laporan Penelitian. Kerjasama Pemda Kabupaten Pegaf dan P2ksdm-Unipa. Tidak Diterbitkan.

Salusu, J. 2003. Pengambilan Kepusan Stratejik Untuk Organisasi Publik Dan Organisasi Nonprofit. Penerbit Grasindo. Jakarta.

Soekartawi, A. Soeharjo, J.L. Dillon dan J. B. Hardaker. 1986. Ilmu Usahatani dan Penelitian Untuk Pengembangan Petani Kecil. Penerbit Universitas Indonesia Press. 
Soekartawi. 2010. Agribisnis.; Teori dan Aplikasinya. Penerbit. Pt Radjagrafindo Persada. Jakarta.

Sudiyono, A. 2004. Pemasaran Pertanian. Penerbit. Universitas Muhammadiyah Malang. Jawa Timur.

Suratiyah, K. 2008. Ilmu Usahatani. Penebar Swadaya. Depok. Bogor.

Susanto, A. Dan M.P. Sirappa. 2005. Prospek dan strategi pengembangan jagung untuk mendukung ketahanan pangan di Maluku. J. Litbang Pertanian. Vol. 24 (2), 2005: 70-79.

Susanto, A. Dan N. Woyanti. 2008. Analisis sektor potensial dan pengembangan wilayah guna mendorong pembangunan di Kabupaten Rembang. Jurnal Media Ekonomi dan Manajemen. Vol. 8 No. 2.

Tim Unipa. 2015. Profil pertanian, peternakan, perkebunan dan perikanan di Kabupaten Pegunungan Arfak Tahun 2015. Laporan. Kerjasama Pemda Kabupaten Pegaf dan Unipa. Tidak Diterbitkan.

Yantewo, A.R. 2015. Efisiensi tataniaga sapi potong di Kabupaten Pegunungan Arfak. Skripsi. Unipa. Tidak Diterbitkan.

Zaini, A. Penentuan komoditi sub sektor tanaman pangan dan hortikultura di Kabupaten Paser. Jurnal Epp. Vol.2 (2). 2007:43-52. 